\title{
The Effects of Glucomannan Hydrolysates and BV Gel on Nugent Score, Treg Cell Percentage, and TGF- $\beta$ level in Bacterial Vaginosis
}

\author{
Ambar Dwi Retnoningrum(1), Tatit Nurseta'), Sumarno Reto Prawiro3) \\ Agustina Tri Endharti4), Endang Sri Wahyuni5) \\ 1)Masters Program in Midwifery, Universitas Brawijaya, Malang \\ 2)Department of Obstetrics and Gynecology, dr. Saiful Anwar Hospital, Malang \\ 3)Department of Microbiology, Faculty of Medicine, Universitas Brawijaya, Malang \\ 4)Department of Parasitology, Faculty of Medicine, Universitas Brawijaya, Malang \\ 5) Department of Physiology, Faculty of Medicine, Universitas Brawijaya,
}

\begin{abstract}
Background: Bacterial vaginosis is commonly experienced by women of reproductive age. The Nugent score is the gold standard for diagnosing bacterial vaginosis. Prebiotic Glucomannan hydrolysates (GMH) as a therapy in the treatment of bacterial vaginosis and has an immunomodulatory effect on the immune system and provides cellular immunity. The purpose of this study was to examine the effects of GMH and BV Gel on Nugent scores, Treg cell presentation, and TGF $\beta$ levels in bacterial vaginosis of women of childbearing age.

Subjects and Method: This was an experimental study. A sample of 24 women aged 20 to 45 years old with bacterial vaginosis (Nugent score $\geq 7$ ) was divided into 4 groups: oral antibiotic group metronidazole (500mg), combination of GMH (300mg) and metronidazole, $5 \mathrm{ml}$ BV Gel tube, and combination of GMH and BV Gel scores. The dependent variables were GMH and BV Gel administrations. The independent variables Nugent score, Treg presentation, and TGF- $\beta$ level. Nugent score, Treg cell presentation, and TGF $\beta$ level were measured on day-o, day-11, and day-22. The data were analyzed by one way Anova.

Results: The results of the analysis after treatment on day 22 showed that the GMH and BV gel were able to reduce Nugent scores, increase Treg cell presentation and TGF $\beta$ levels in bacterial vaginosis of women of childbearing age.

Conclusion: GMH as an alternative therapy for bacterial vaginosis compared with antibiotic treatment can improve normal vaginal flora and stimulate the immune system in vitro and in vivo significantly.
\end{abstract}

Keywords: Glucomannan Hydrolysates, $B V G e l$, Nugent sel Treg score, TGF $\beta$

Correspondence:

Ambar Dwi Retnoningrum. Masters Program of Midwifery, Universitas Brawijaya, Malang, East Java. Email: adreambar@gmail.com. Mobile: +6281335743696.

\section{BACKGROUND}

Vaginal infection is not a direct cause of maternal death, but is a cause of high morbidity in women (Palmeira-de-Oliveira et al., 2015). The most common cause of vaginitis is bacterial vaginosis (22\% to $50 \%$ of symptomatic women), vulvovaginal candidiasis (17\% to $39 \%)$, and trichomoniasis (4\% to 35\%) (Beckmann et al., 2010).

Bacterial vaginosis is the most common cause of abnormal vaginal expenditure in women of childbearing age. This is a syndrome with no known cause characterized by reduced Lactobacillus population and excessive growth of anaerobic bacteria in the vagina, accompanied by loss of vaginal acidity (Hay, 2014). The Nugent Score has good objectivity, sensitivity and specificity, which is the gold standard for diagnosing BV infections (Bhat et al., 2011; Rodrigues et al., 2015). 
The use of metronidazole antibiotics is the most commonly given antibiotic by $74.3 \%$ in BV cases (Pujiastuti and Murtiastutik, 2014), but can cause $30 \%$ of BV recurrences again after 4 weeks of treatment. Resistance from antibiotic use associated with $\mathrm{BV}$ has been reported so that a new therapeutic strategy is needed (Workowski and Berman, 2011; Bradshaw, 2006; Ferris, 2004; Beigi, 2004). Several studies on prebiotics containing oligosaccharides, sukroka, prebiotic gel (BV gel) as an alternative to BV therapy (Roberfroid, 2007; Zeng, 2010; Coste, 2012). Several clinical trials have reported that the use of plant compounds in reducing BV symptoms includes polyherbal vaginal pessaries (Patel et al., 2008). The use of prebiotic Glucomannan hydrolysates (GMH) $200 \mathrm{mg}$ in patients with vaginal infections is as a therapy in the improvement of normal vaginal flora (Tester et al., 2012).

Glucomannan hydrolysates (GMH) has an immunomodulatory effect on the development of the body's immune system, providing humoral, cellular and mucosal immunity. Immunomodulators of Lactobacillus may be due to their ability to induce cytokines, regulate innate immune responses and adaptive immune responses (Lin et al., 2010). Several studies have shown that different species of bacteria have the ability in the immune system, antigen-specific $\mathrm{T}$ polarization including Treg cells (Mohamadzadeh et al., 2005). Large populations of TCD4 + cells express CD25 + on surfaces that are thought to affect the immune response (Kumar et al., 2013). Only one study reported the effect of $\mathrm{BV}$ on the percentage of Treg cells in peripheral blood mononuclear cells (PBMCs), that Treg reduction was only observed in $\mathrm{BV}+/ \mathrm{HIV}+$ women compared to BV-/ HIV+ women (Schellenberg et al., 2012).
Cytokines and chemokines regulate many functions of the body's immunity in the female reproductive tract (Hickey et al., 2011). One of the important mediators of mature signals on the mucosal effector site is the Transforming Growth Factor-beta (TGF- $\beta$ ). The pattern of cytokine response to L. Crispatus evaluated in superficiality of cell cultures reported that immunoregulatory cytokines, including TGF- $\beta$ and IL10, detected the highest concentration compared to Th1 type (IFN- $\gamma$ and IL-12) and type Th2 (IL-4) has a lower concentration detected (Alvarez-Olmos et al., 2004; Levings et al., 2002). In BV, the role of the infecting agent regulates its integrin expression, it has been reported that integrin expression is regulated by cytokines such as changes in TGF- $\beta$. The TGF- $\beta$ signaling pathway must be hypothetically activated by various active microbial components through the Toll-like receptor (TLR) (Biswal et al., 2014)

Molecular analysis of bacterial vaginosis is an additional method that is prospectively useful for clinical and microscopic analysis of identifying patients at high risk of bacterial vaginosis recurrence (Hilbert et al., 2016). The purpose of this study is to prove the effect of GMH and BV Gel on Nugent scores, Treg cell presentation, and TGF $\beta$ levels in bacterial vaginosis of women in childbearing age.

\footnotetext{
SUBJECTS AND METHOD

\section{Study Design}

This study was a true experimental using in vivo pretest posttest group design, conducted on bacterial vaginosis patients to determine $\mathrm{T}$ regulator presentation and TGF- $\beta$ levels before and after GMH and BV Gel administration.
}

\section{Population and Samples}

The population of this study were patients diagnosed with bacterial vaginosis of wo- 
men of childbearing age (20 to 45 years) at Department of Obstetrics and Gynecology, dr. Iskak Hospital, Tulungagung, East Java. The bacterial vaginosis diagnosis was based on gram bacterial staining that was assessed based on Nugent's score table.

The sample in this study amounted to 24 people, divided into 4 groups, each group amounted to 6 people, namely: Group P1 given therapy Antibiotic Metronidazole taken at a dose of $500 \mathrm{mg}, 2$ times a day for 7 days.

Group P2 was given Metronidazole taken at a dose of $500 \mathrm{mg}, 2 \mathrm{x}$ daily for 7 days and also given a pessary therapy containing $300 \mathrm{mg}$ GMH inserted into the vaginal opening, patients were given pessary 3 times a week and recommended to be used before going to bed for 21 days.

The $\mathrm{P}_{3}$ group was given a therapy in the form of BV Gel products used according to the manufacturer's instructions, once a day for 7 days. $\mathrm{P} 4$ group was given pessary therapy containing $300 \mathrm{mg}$ GMH 3 times a week and performed before going to bed for 21 days and given BV Gel product therapy according to factory instructions the maker, once a day for 7 days.

\section{Study Variables}

The dependent variable of this study was Nugent score, Treg cell and TGF- $\beta$ cytokine. The independent variables include BV Gel, Glucomannan Hydrolysates (GMH) and $\mathrm{GMH}+\mathrm{BV}$ Gel Combinations.

\section{Operational Definition of Variables} Glucomannan hydrolysates (GMH) in the form of prebiotic capsules containing polysaccharides from the plant Amorphopallus konjac are administered vaginally. The ratio measurement scale was by giving $300 \mathrm{mg}$ GMH capsules.

BV Gel is the one containing Lactic acid, Glycogen, Propylene Glycol, Methylhydroxy Propyl cellulose, sodium lactate, water, and $\mathrm{pH}$ 3.8. Scale ratio measurement was by giving $5 \mathrm{ml}$ tube.

Antibiotics was used generic metronidazole tablets. Scale measurement ratio was by giving $500 \mathrm{mg} /$ per oral.

Nugent scores by examining vaginal secretions that have been stained with Gram staining bacteria observed under microscope, are assessed and scored according to Nugent criteria. The ratio measurement scale was by calculating the number $o$ to 10 based on Nugent's table.

Regulatory T cells (Treg) were observed Treg cells from Pheripheral Blood Mononuclear Cells (PBMC) in total CD4+ CD25+ Foxp3 of ten thousand cell populations using flowcitometry (Bio-legend). The ratio measurement scale was read with FACS CaliburTM flowcytometry with cellQuest Pro software with percent (\%) units.

TGF $\beta$ levels were cytokines observed from blood plasma using the Human TGF $\beta$ Elisa Kit (Bio-legend). The ratio measurement scale with Bio Rad 550 microplate reader, expressed in units of $\mathrm{pg} / \mathrm{mL}$.

The measurement of Nugent's score, Treg cell presentation and TGF $\beta$ levels was carried out in 3 (three) measurements, namely on day o (Ho) before treatment, day 11 (H11) and day 22 (H22) on 4 (four) sample groups.

\section{Data Analysis}

Data analysis was done using Shapiro-Wilk normality test because the sample was 50 , while the comparison test was use One Way Anova.

\section{Research Ethics}

This study was carried out after obtained a permit from the Ethics Committee of Tulungagung Hospital. All bacterial vaginosis patients were sign informed consent before the study. Ethichal clearance was issued by the Research Ethics Committee of the Regional General Hospital Dr. Iskak 
Indonesian Journal of Medicine (2018), 3(1): 33-43

https://doi.org/10.26911/theijmed.2018.03.01.05

Tulungagung with Number 070/1992 /407.206/ 2017.

\section{RESULTS}

The results of staining gram bacteria on a microscope

Gram bacterial staining was observed on a microscope, then the assessment results using the Nugent score table and before the Nugent score treatment $\geq 7$ were included in the pre-treatment research inclusion criteria (Figure 1).

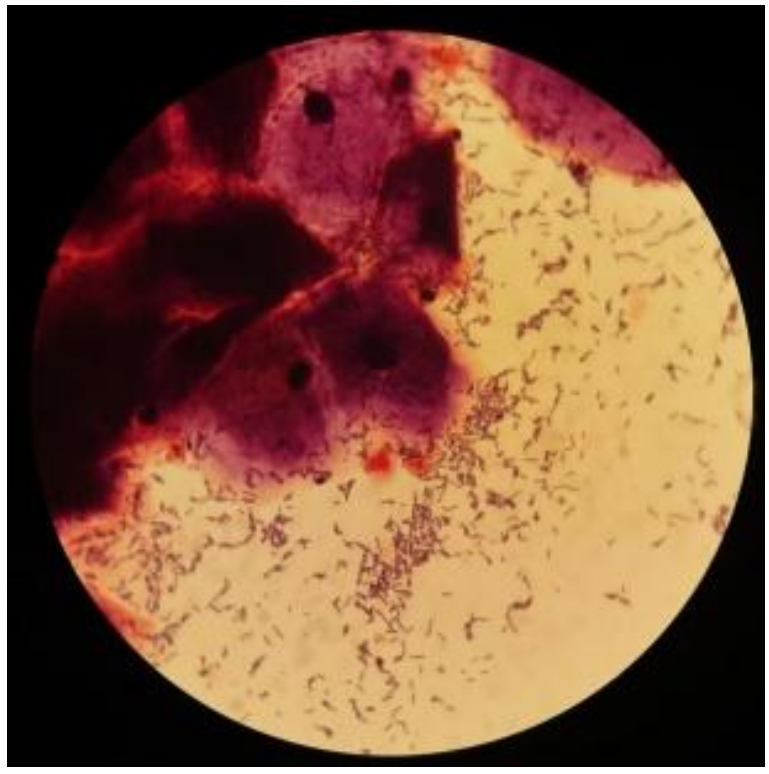

Figure 1. Bacterial Gram (Day-o)

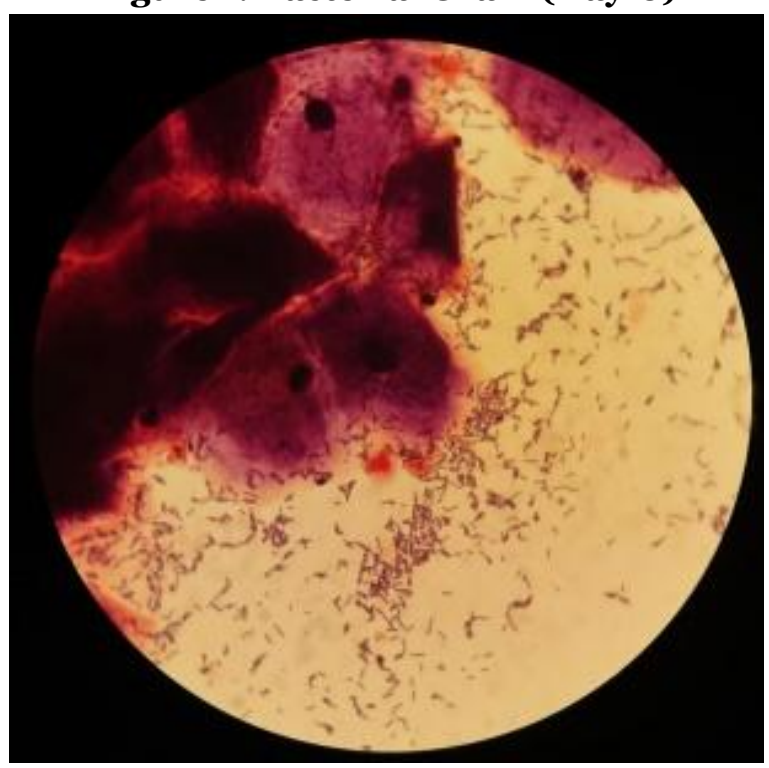

Figure 2. Bacterial Gram (Day-11)

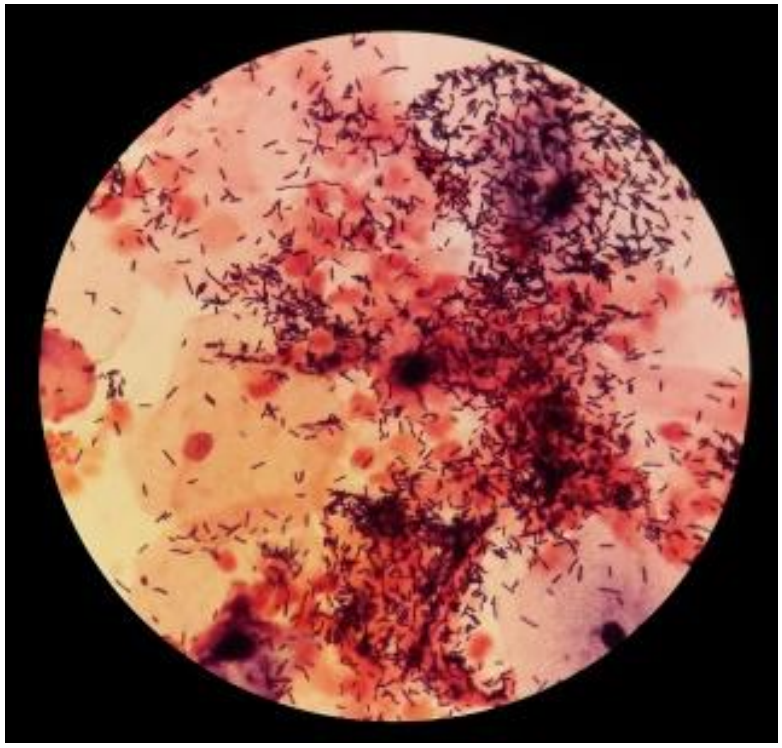

Figure 3. Bacterial Gram (Day-22)

After giving the treatment and observing gram bacteria on a microscope that showed the characteristics of the Lactobacillus $s p$ normal flora, then an assessment was conducted by using Nugent score table on day-22 (Figure 3).

Based on the results of the ShapiroWilk test in Table 1, it was found that Nugent score data, Treg cell counts, and TGF- $\beta$ levels for each observation group had shown all the $\mathrm{p}$ values which were normally distributed.

The highest average Nugent score was on day o of observations, then Nugent's average score decreased on the $11^{\text {th }}$ day of observation, and it experienced another decrease on the $22^{\text {nd }}$ day of observation. In women of reproductive age who have bacterial vaginosis and got $\mathrm{GMH}$ and $\mathrm{BV}$ Gel, it showed a decrease in Nugent scores on day 22 compared to before the application (day $\mathrm{O}$ ). The combination of GMH and BV Gel obtained on D-o, D-11 and D-22 had significant differences, which mean that the Nugent score had a significant decrease (Table 2).

The lowest average number of Treg cells was in the observation of the oth day before treatment, then the average number 
of Treg cells increased in the $11^{\text {th }}$ day of observations and it experienced another enhancement in the $22^{\text {nd }}$ day of observations. In women of reproductive age who have bacterial vaginosis which given a combination of GMH and BV Gel, it showed the presetation results that Treg cell was increased and there were significant differences on D-O, D-11 and D-22 (Table 3).

In this study, the lowest TGF- $\beta$ levels was in the $\mathrm{O}^{\text {th }}$ day of observations day before treatment, then the average of TGF$\beta$ level increased in the $11^{\text {th }}$ day of observations and experienced another enhancement in the $22^{\text {nd }}$ day of observations. The assessment of TGF- $\beta$ levels in the combination group of GMH and BV Gel showed that TGF- $\beta$ levels had increased and there were significant differences in D-O, D-11, and D-22 (Table 4).

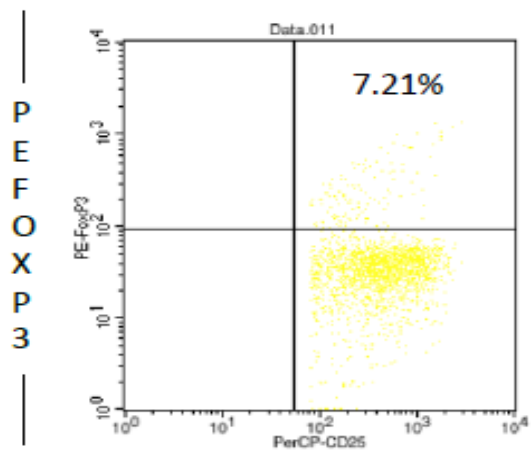

$\mathrm{HO}$

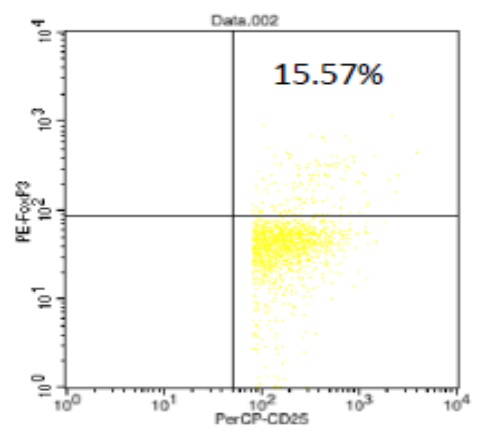

PerCP-CD25

$\mathrm{H} 11$

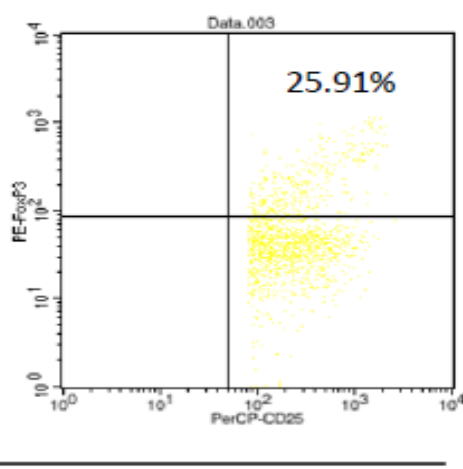

$\mathrm{H} 22$

Figure 4. The Results of Treg Cell Presentation Measurement with Flowecitometry

The Results of Parametric Prerequisite Test

Table 1. Normality Test Results

\begin{tabular}{|c|c|c|c|c|c|}
\hline \multirow[b]{2}{*}{ Groups } & \multirow[b]{2}{*}{$\begin{array}{c}\text { Observation } \\
\text { Day }\end{array}$} & \multicolumn{3}{|c|}{$\mathbf{p}$} & \multirow[b]{2}{*}{ Distribution } \\
\hline & & $\begin{array}{l}\text { Nugent } \\
\text { Score }\end{array}$ & $\begin{array}{c}\text { Number of } \\
\text { Teg Cells }\end{array}$ & TGF- $\beta$ Levels & \\
\hline \multirow{3}{*}{ P1 } & Ho & 0.415 & 0.545 & 0.692 & Normal \\
\hline & H11 & 0.554 & 0.192 & 0.991 & Normal \\
\hline & $\mathrm{H} 22$ & 0.933 & 0.824 & 0.404 & Normal \\
\hline \multirow{3}{*}{$\mathbf{P 2}$} & Ho & 0.191 & 0.346 & 0.884 & Normal \\
\hline & H11 & 0.059 & 0.107 & 0.497 & Normal \\
\hline & $\mathrm{H} 22$ & 0.452 & 0.472 & 0.514 & Normal \\
\hline \multirow{3}{*}{ P3 } & Ho & 0.091 & 0.183 & 0.233 & Normal \\
\hline & H11 & 0.480 & 0.142 & 0.425 & Normal \\
\hline & $\mathrm{H} 22$ & 0.212 & 0.985 & 0.213 & Normal \\
\hline \multirow{3}{*}{ P4 } & Ho & 0.820 & 0.558 & 0.634 & Normal \\
\hline & H11 & 0.111 & 0.345 & 0.662 & Normal \\
\hline & $\mathrm{H} 22$ & 0.093 & 0.688 & 0.588 & Normal \\
\hline
\end{tabular}


Indonesian Journal of Medicine (2018), 3(1): 33-43

https://doi.org/10.26911/theijmed.2018.03.01.05

Table 2. The Results of Average Comparison of Nugent Score

\begin{tabular}{ccccc}
\hline Groups & \multicolumn{4}{c}{ Means \pm SD } \\
\cline { 2 - 5 } & P1 & P2 & P3 & P4 \\
\hline Ho & $8.33 \pm 1.21^{\mathrm{a}}$ & $8.50 \pm 1.38^{\mathrm{a}}$ & $8.67 \pm 0.82^{\mathrm{a}}$ & $8.50 \pm 1.05^{\mathrm{a}}$ \\
\hline H11 & $6.67 \pm 1.37^{\mathrm{a}}$ & $5.67 \pm 1.75^{\mathrm{b}}$ & $4.33 \pm 1.63^{\mathrm{b}}$ & $3.50 \pm 1.76^{\mathrm{b}}$ \\
\hline H22 & $4.00 \pm 2.00^{\mathrm{b}}$ & $3.17 \pm 1.94^{\mathrm{c}}$ & $3.33 \pm 1.51^{\mathrm{b}}$ & $1.33 \pm 1.37^{\mathrm{c}}$ \\
\hline $\mathbf{P}$ & 0.001 & $<0.001$ & $<0.001$ & $<0.001$ \\
\hline
\end{tabular}

Table 3. Comparative Test Results for Average Presentation of Treg Cells

\begin{tabular}{ccccc}
\hline Groups & \multicolumn{4}{c}{ Means \pm SD } \\
\cline { 2 - 5 } & P1 & P2 & P3 & P4 \\
\hline Ho & $7.78 \pm 1.87^{\mathrm{a}}$ & $7.62 \pm 2.03^{\mathrm{a}}$ & $9.14 \pm 5.26^{\mathrm{a}}$ & $8.10 \pm 2.35^{\mathrm{a}}$ \\
\hline H11 & $11.15 \pm 5.37^{\mathrm{a}}$ & $11.59 \pm 4.10^{\mathrm{b}}$ & $14.11 \pm 6.32^{\mathrm{a}}$ & $15.42 \pm 4.96^{\mathrm{b}}$ \\
\hline H22 & $17.83 \pm 4.68^{\mathrm{b}}$ & $19.67 \pm 2.78^{\mathrm{c}}$ & $22.19 \pm 2.77^{\mathrm{b}}$ & $22.62 \pm 7.53^{\mathrm{c}}$ \\
\hline P & 0.003 & $<0.001$ & 0.001 & 0.001 \\
\hline
\end{tabular}

Table 4. The Results of Average Comparison of TGF- $\beta$ Levels

\begin{tabular}{ccccc}
\hline \multirow{2}{*}{ Groups } & \multicolumn{4}{c}{ Means \pm SD } \\
\cline { 2 - 5 } & P1 & P2 & P3 & P4 \\
\hline Ho & $429.99 \pm 3.82^{\mathrm{a}}$ & $429.44 \pm 6.72^{\mathrm{a}}$ & $429.57 \pm 4.55^{\mathrm{a}}$ & $428.83 \pm 4.63^{\mathrm{a}}$ \\
\hline H11 & $430.71 \pm 4.68^{\mathrm{a}}$ & $431.14 \pm 2.88^{\mathrm{a}}$ & $431.78 \pm 5.16^{\mathrm{a}}$ & $434.74 \pm 3.78^{\mathrm{b}}$ \\
\hline H22 & $439.18 \pm 4.51^{\mathrm{b}}$ & $439.77 \pm 3.18^{\mathrm{b}}$ & $440.65 \pm 3.27^{\mathrm{b}}$ & $441.19 \pm 3.52^{\mathrm{c}}$ \\
\hline p & 0.004 & 0.003 & 0.001 & $<0.001$ \\
\hline
\end{tabular}

\section{DISCUSSION}

\section{The Effect of GMH and BV Gel on Nugent Score}

The combination of GMH and BV Gel obtained in Ho, H11 and H22 has a significant difference which mean that the Nugent score experienced a significant decrease. The cure rate of women who were given antibiotics was higher $(58 \%-100 \%)$ than the cure rate of women who were given placebo (5\% -29\%) when evaluated 4 weeks after treatment (Oduyebo, 2009; Menard, 2011). Lactobacilli evaluation based on the Nugent score at 5-7-days of visit showed a higher Lactobacilli enhancement in the sucrose gel group compared to the metronidazole group. This result indicated that by triggering the growth of Lactobacilli, sucrose gel returned the vaginal normal flora faster than metronidazole (Menard,
2011). The comparison of the effectiveness of prebiotic gel containing sucrose with $0.75 \%$ metronidazole vaginal gel in the $\mathrm{BV}$ treatment (Zeng et al., 2010).

Glucomannan hydrolysates which produced with mannanase or cellulase enzymes were carbon sources of lactic cellulase acid and hydrolyzate bacteria which were most important for lactic acid bacteria (Al-Ghazzewi dan Tester, 2012).

The use of cellulase or mannanase to hydrolyze konjac glucomannan could produce effective prebiotic substrate formation. (Al-Ghazzewi et al., 2007; Huang et al., 2007).

In vitro culture tests on seventeen species of anaerobic bacteria related to BV and four species of vaginal Lactobacilli which were given $\mathrm{H}_{2} \mathrm{O} 2$, lactic acid, or acetic acid at $\mathrm{pH} 7.0$ and $\mathrm{pH}$ 4.5, were 
evaluated after two hours, physiological concentrations of lactic acid killed the BVrelated bacteria without affecting vaginal Lactobacilli, while physiological concentrations of $\mathrm{H}_{2} \mathrm{O} 2$ did not properly activate the BV-related bacteria or lactobacilli vagina. $\mathrm{H}_{2} \mathrm{O} 2$ was more toxic to vaginal lactobacilli than BV-related bacteria. On the basis of this in vitro observation, it could be seen that lactic acid, not $\mathrm{H}_{2} \mathrm{O} 2$, was more likely to suppress BV-related bacteria in vivo (O'Hanlon et al., 2011).

Evaluation, efficacy, and other safety of prebiotic gels were applied as adjuvant therapy. Women who were treated for BV and showed the recovery from normal vaginal flora reduced the risk of recurrence (Coste et al., 2012). BV Gel which contained lactic acid could effectively increase the acidity of vaginal $\mathrm{pH}$. Lactic acid was important in maintaining vaginal health, because it created an acidic $\mathrm{pH}$ that support the enhancement of Bacillus acidophilus and inhibit the growth of pathogens (Petrova, et al., 2015).

\section{The Effect of GMH and BV Gel on Treg Cell Presentation}

In women of reproductive age who have bacterial vaginosis and got a combination of GMH and BV Gel, the results of Treg cell presentation experienced an enhancement, and there were significant differences on Do, D-11, and D-22.

Nowadays, all prebiotics were known as carbohydrates, and there were many different carbohydrates which distributed worldwide as prebiotics (O'Bryan et al., 2013). Carbohydrate receptors on the microbial surface phagocytized the microbes and secreted the cytokines to activate the adaptive immune response (Abbas et al., 2015). Prebiotics can stimulate the growth of probiotics Lactobacillus sp. These probiotics can work by involving the type of $\mathrm{T}$ cells, Treg cells (the regulation of $\mathrm{T}$ cells down of the immune system by producing release of cytokines IL-10), thus increasing the number of Treg cells in the body, while also having the ability of immunoregulators mediated by regulator $\mathrm{T}$ cells to provide therapeutic benefits by inhibiting the growth of several harmful Gram-negative and Gram-positive bacteria which could lead to antimicrobial effects (Huber, et al., 2011).

The anti-inflammatory effects of probiotics might depend on several mechanisms, such as adhesion to the epithelial barrier and antimicrobial effects. The relationship of regulator $\mathrm{T}$ cells and cytokines related to the function of probiotics could increase the regulation of cytokines which played a major role in the protective effect of probiotics. The effects of probiotics which interact with the mucosa of dendritic cell produced their own regulatory cytokines or induce the $\mathrm{T}$ cells to obtained a stronger regulatory cell response (Boirivant and Strober, 2007). Other study explained that Lactobacillus sp. have immunomodulatory effects (Jeon, 2012) which could induce $\mathrm{CD}_{4}+$ Treg CD4+ Treg (Rosseli, 2009).

\section{The Effect of GMH and BV Gel on TGF- $\beta$ Level}

The assessment of TGF- $\beta$ levels in the combination group of GMH and BV Gel showed that the TGF- $\beta$ levels had increased and there were significant differences in Do, D-11, and D-22.

The combination of prebiotic inulin and oligofructose in the treatment of colitis in transgenic rats reduced the proinflammatory cytokines such as IL-1 $\beta$ and IFN- $\gamma$, and increased the TGF- $\beta$ and immunomodulatory molecules (Hoentjen et al., 2005). The probiotics activated the TGF- $\beta$ through the SMAD signal pathway which lead to TLR2 degradation in epithelial cells. The enhancement of TGF- $\beta$ produced SMAD signals which found in 
peripheral blood mononuclear cells (Fujii et al., 2006; Vinderolan et al., 2005). Lactic acid (LA) has a direct effect on cervicovaginal epithelial cells to induce an antiinflammatory state, which were substantially characterized by increased production of anti-inflammatory cytokines, and a reduction in the production of pro-inflammatory cytokines. Furthermore, LA was able to protect cervico-vaginal epithelial cells from inflammation which caused by TLR agonists, and it significantly affected the production of cytokines and inflammatory chemokines in LA presentations. The effect of LA to prevent the production of pro-inflammatory mediators of cervicovaginal epithelial cells was suspected that LA could inhibit the inflammation induced by pathogen-associated molecular patterns (PAMPS), from various pathogenic bacterias and viruses (Anahtar et al., 2015; Arnold et al., 2016; Hearps et al., 2017; Ferreira et al., 2011).

Various studies of different cell hosts/cultures showed a beneficial effect of prebiotics on immune system function, by regulating the expression of proinflammatory cytokines and anti-inflammatory cytokines (Shokryazdan et al., 2016). However, most studies considered the indirect effects of prebiotics on the immune system, where prebiotics improved immune function through increased population of normal vaginal flora (probiotics), and reduced the pathogenic bacteria at the same time.

\section{REFERENCES}

Abbas AK, Lichtman AH, Pillai S (2015). Cellular and Molecular Immunology, Edisi 8, Elsevier Saunders, Philadelphia.

Al-Ghazzewi FH, Tester RF (2012). Efficacy of cellulase and mannanase hydrolysates of konjac glucomannan to promote the growth of lactic acid bacteria, Journal of the Science of Food and Agriculture, 92(11): pp. 2394-2396. doi:10.1002/jsfa.5678.

Alvarez-Olmos MI, Barousse MM, Rajan L, Van Der Pol BJ, Fortenberry D, Orr D, Fidel JRP (2004). Vaginal lactobacilli in adolescents: presence and relationship to local and systemic immunity, and to bacterial vaginosis, Sexually transmitted diseases, 31(7): 393 400. doi: 10.1097/01.OLQ.0000130454.83883.E9.

Anahtar MN, Byrne EH, Doherty KE, Bowman BA, Yamamoto HS, Soumillon M, Padavattan N, et al. (2015). Cervicovaginal bacteria are a major modulator of host inflammatory responses in the female genital tract. Immunity 42:965-976.

Arnold KB, Burgener A, Birse K, Romas L, Dunphy LJ, Shahabi K, Abou M et al. (2016). Increased levels of inflammatory cytokines in the female reproductive tract are associated with altered expression of proteases, mucosal barrier proteins, and an influx of HIV-susceptible target cells. Mucosal Immunol. 9, 194-205. doi:10.1038/mi.2015.51.

Beckmann CRB. Ling FW, Barzansky BM, Herbert WNP, Laube DW, Smith RP (2010). Obstetrics and Gynecology, Ed. 6, Lippincott Williams \& Wilkins, Wolters Kluwer Health, Philadelphia.

Beigi RH, Austin MN, Meyn LA, Krohn MA, Hillier SL (2004). Antimicrobial resistance associated with the treatment of bacterial vaginosis. American journal of obstetrics and gynecology, 191(4): 1124-1129.

Bhat G, Kotigadde S, Shenoy S (2011). Comparison of the methods of diagnosis of bacterial vaginosis, Journal of Clinical and Diagnostic Research, 5(3): 498-501. 
Biswal BM, Singh KKB, Ismail MB, Jalal MIBA, Safruddin EISBE (2014). Current Concept of Bacterial Vaginosis in Cervical Cancer, Journal of Clinical Gynecology and Obstetrics, 3(1): 1-7 doi:http://dx.doi.org/10.14740/jcgo175w.

Boirivant M, Strober W (2007). The mechanism of action of probiotics, Current opinion in gastroenterology, 23(6): 679-692.

Bradshaw CS, Morton AN, Hocking J, Garland SM, Morris MB, Moss LM, Fairley CK (2006). High recurrence rates of bacterial vaginosis over the course of 12 months after oral metronidazole therapy and factors associated with recurrence. Journal of Infectious Diseases, 193(11): 14781486.

Coste I, Judlin P, Lepargneur JP, BouAntoun S (2012). Safety and efficacy of an intravaginal prebiotic gel in the prevention of recurrent bacterial vaginosis: a randomized double-blind study, Obstetrics and gynecology international.

Ferreira VH, Nazli A, Khan G, Mian MF, Ashkar AA, Owen SG, Kaul R, Kaushic C (2011). Endometrial epithelial cell responses to coinfecting viral and bacterial pathogens in the genital tract can activate the HIV-1 LTR in an NFkB-and AP-1-dependent manner. The Journal of Infectious Diseases. 204(2): 299-308.

Ferris MJ, Masztal A, Aldridge KE, Fortenberry JD, Fidel PL, Martin DH (2004). Association of Atopobium vaginae, a recently described metronidazole resistant anaerobe, with bacterial vaginosis. BMC infectious diseases, 4(1), 5 .

Fujii T, Ohtsuka Y, Lee $\mathrm{T}$ (2006). Bifidobacterium breve enhances trans- forming growth factor beta1 signaling by regulating $\mathrm{Smad} 7$ expression in preterm infants. $\mathrm{J}$ Pediatr Gastroenterol Nutr. 43:83-88.

Hay P (2014). Bacterial Vaginosis, Medicine, 42(7) Elsevier: 359-363

Hearps AC, Tyssen D, Srbinovski D, Bayigga L, Diaz DJD, Aldunate M, Tachedjian G (2017). Vaginal lactic acid elicits an anti-inflammatory response from human cervicovaginal epithelial cells and inhibits production of pro-inflammatory mediators associated with HIV acquisition. Mucosal Immunology.

Hickey DK, Patel MV, Fahey JV, Wira CR (2011). Innate and adaptive immunity at mucosal surfaces of the female reproductive tract: stratification and integration of immune protection against the transmission of sexually transmitted infections, Journal of reproductive immunology, 88(2): 185-194.

Hilbert DW, Smith WL, Paulish-Miller TE, Chadwick SG, Toner G, Mordechai E, , Adelson ME, et al. (2016). Utilization of molecular methods to identify prognostic markers for recurrent bacterial vaginosis, Diagnostic Microbiology and Infectious Disease, 86(2): 231-242.

Hoentjen F, Welling GW, Harmsen HJ, Zhang X, Snart J, Tannock GW, Lien K, Churchill TA, Lupicki M, Dieleman LA (2005) Reduction of colitis by prebiotics in HLA-B27 transgenic rats is associated with microflora changes and immunomodulation. Inflamm Bowel Dis 11:977-985.

Huber S, Gagliani N, Esplugues E, O'connor W, Huber FJ, Chaudhry A, Kamanaka M, et al. (2011). Th17 cells express interleukin-10 receptor and are controlled by Foxp3- and Foxp3+ regulatory $\mathrm{CD} 4+\mathrm{T}$ cells in an interleukin- 
10-dependent manner. Immunity, 34 (4): 554 - 565. https://doi.org/10.1016/j.immuni.2011.01.020.

Jeon SG, Kayama H, Ueda Y, Takahashi T, Asahara T, Tsuji H, Tsuji NM, et al. (2012). Probiotic Bifibacterium breve induces IL-10 prodicing Tr1 cells in the colon. PLoS One. 8. e 1002714. https://doi.org/10.1371/journal.ppat.1002714.

Kumar S, Naqvi RA, Ali R, Rani R, Khanna $\mathrm{N}$, Rao DN (2013). CD4+CD25+Tregs with acetylated FoxP3 are associated with immunesuppression in human leprosy, Molecular Immunology, 56: 513-520. http://dx.doi.org/10.1016/j.molimm.2013.04.015.

Levings MK, Bacchetta R, Schulz U, Roncarolo MG (2002). The role of IL-10 and TGF- $\beta$ in the differentiation and effector function of $\mathrm{T}$ regulatory cells, International archives of allergy and immunology, 129(4): pp. 263-276.

Lin HM, Pang J, Fan LL, Chen J (2010). Advances in immunological activities of Konjac glucomannan. Chinese Pharmacological Bulletin, 26(11): 1404-1406.

Menard JP (2011). Antibacterial treatment of bacterial vaginosis: current and emerging therapies. International journal of women's health, 3, 295

Mohamadzadeh M, Olson S, Kalina WV, Ruthel G, Demmin GL, Warfield KL, Bavari S, Klaenhammer TR (2005). Lactobacilli activate human dendritic cells that skew $\mathrm{T}$ cells toward $\mathrm{T}$ helper 1 polarization, Proceedings of the National Academy of Sciences of the United States of America, 102(8): 2880-2885.

Nugent RP, Krohn MA, Hillier SL (1991). Reliability of diagnosing bacterial vaginosis is improved by a standardized method of gram stain inter- pretation, Journal of clinical microbiology, 29(2): 297-301.

O’Bryan C, Pak D, Crandall P, Lee S, Ricke $S$, (2013). The role of prebiotics and probiotics in human health, $J$ Prob Health, 1(108): 2.

O'Hanlon DE, Moench TR, Cone RA (2011). In vaginal fluid, bacteria associated with bacterial vaginosis can be suppressed with lactic acid but not hydrogen peroxide, BMC infectious diseases, 11(1): 200.

Oduyebo OO, Anorlu RI, Ogunsola FT (2009). The effects of antimicrobial therapy on bacterial vaginosis in nonpregnant women. Cochrane Database Syst Rev. 3:CDoo6055.

Palmeira-de-Oliveira R, Palmeira-de-Oliveira A, Martinez-de-Oliveira J (2015). New strategies for local treatment of vaginal infections, Advanced drug delivery reviews, 92: 105-122 http://dx.doi.org/10.1016/j.addr.2015 .06.008.

Patel Y, Gopalan S, Bagga R, Sharma M, Chopra S, Sethi S (2008). A randomized trial comparing a polyherbal pessary (a complementary and alternative medicine) with Ginlac-V pessary (containing clotrimazole, tinidazole and lactobacilli) for treatment of women with symptomatic vaginal discharge. Archives of gynecology and obstetrics, 278(4): 341-347.

Petrova MI, Lievens E, Malik S, Imholz N, Lebeer S (2015). Lactobacillus species as biomarkers and agents that can promote various aspects of vaginal health, Frontiers in physiology, 6: 81.

Pujiastuti AT, Murtiastutik D (2014). Studi Retrospektif: Vaginosis Bakterial. Berkala Ilmu Kesehatan Kulit dan Kelamin, Periodical of Dermatology and Venereology. 26(2): 127-133. 
Roberfroid M (2007). Prebiotics: the concept revisited. J.Nutr. 137: 830S$837 \mathrm{~S}$.

Rodrigues FS, Peixoto S, Adami F, Alves BDCA, de Sousa Gehrke F, Azzalis LA, De Campos, Junqueira VB, Fonseca FLA (2015). Proposal of a new cutoff for Nugent criteria in the diagnosis of bacterial vaginosis, Journal of microbiological methods, 115: 144-146

Roselli M, Finamore A, Nuccitelli S, Carnevali $\mathrm{P}$, Brigidi $\mathrm{P}$, Vitali $\mathrm{B}$, Mengheri E (2009). Prevention of TNBS induced colitis by different Lactobacillus and Bifidobacterium strains is associated with an expansion of $\gamma \delta \mathrm{T}$ and regulatory $\mathrm{T}$ cells of intestinal intraepithelial lymphocytes. Inflammatory bowel diseases, 15(10), 1526-1536

Schellenberg JJ, Card CM, Ball TB, Mungai $\mathrm{JN}$, Irungu $\mathrm{E}$, Kimani J, Jaoko W (2012). Bacterial vaginosis, HIV serostatus and T-cell subset distribution in a cohort of East African commercial sex workers: retrospective analysis, Aids, 26(3): 387-393

Shokryazdan P, Jahromi MF, Navidshad B, Liang JB (2016). Effects of prebiotics on immune system and cytokine expression. Medical microbiology and immunology, 206(1): 1-9. doi: 10.1007/s00430-016-0481-y

Tester R, Al-Ghazzewi F, Shen N, Chen Z, Chen F, Yang J, Zhang D, Tang M, (2012). The use of konjac glucomannan hydrolysates to recover healthy microbiota in infected vaginas treated with an antifungal agent, Beneficial microbes, 3(1): 61-66. doi: 10.3920/BM2011.0021

Vinderolan G, Matar C, Perdigon G (2005). Role of intestinal epithelial cells in immune effects mediated by grampositive probiotic bacteria: involvement of toll-like receptors. Clinical and diagnostic laboratory immunology, 12(9): 1075-1084

Workowski KA, Berman SM (2011). Centers for Disease Control and Prevention sexually transmitted disease treatment guidelines. Clinical infectious diseases, 53 (3): S59-S63.

Zeng ZM, Liao QP, Yao C, Geng L, Feng LH, Shi HR, Xin XY, et al. (2010). Directed shift of vaginal flora after topical application of sucrose gel in a phase III clinical trial: a novel treatment for bacterial vaginosis, Chinese medical journal, 123(15): 2051-2057. 